\title{
Predicting the life time of steels in CCS environment from long term local corrosion experiments
}

\author{
A. Pfennig ${ }^{1}$, S. Schulz ${ }^{1}$, T. Werlitz ${ }^{1}$, E. Bülow ${ }^{1}$, S. Wetzlich ${ }^{1}$, \\ J. Tietböhl ${ }^{1}$, C. Frieslich ${ }^{1} \&$ A. Kranzmann ${ }^{2}$ \\ ${ }^{1} H T W$ University of Applied Sciences, Berlin, Germany \\ ${ }^{2}$ BAM Federal Institute of Materials Research and Testing, \\ Berlin, Germany
}

\begin{abstract}
To predict the reliability and safety during the injection of compressed emission gases - mainly containing $\mathrm{CO}_{2}$ - into deep geological layers (CCS-technology, Carbon Capture and Storage), the influence of heat treatment on pit corrosion needs to be considered. Different heat treated steels used as an injection pipe with $13 \%$ chromium and $0.46 \%$ carbon $(\mathrm{X} 46 \mathrm{Cr} 13,1.4034)$ and $0.2 \%$ carbon (X20Cr13, 1.4021) as well as $16 \%$ chromium steel $\mathrm{X} 5 \mathrm{CrNiCuNb} 16-4$ (1.4542) were tested in laboratory experiments. The samples were exposed for up to 1 year to the distinct synthetic aquifer environment saturated with technical $\mathrm{CO}_{2}$ at a flow rate of $31 / \mathrm{h}$. The corrosion rate generally does not exceed $0.03 \mathrm{~mm} /$ year. Pits with maximum pit heights around $300 \mu \mathrm{m}$ were obtained for hardened $\mathrm{X} 20 \mathrm{Cr} 13$ with martensitic microstructure. The least amount of pits is found on $\mathrm{X} 46 \mathrm{Cr} 13$. The higher carbon content in, $\mathrm{X} 46 \mathrm{Cr} 13(0.46 \% \mathrm{C})$, results in a lower amount of pits compared to $\mathrm{X} 20 \mathrm{Cr} 13(0.20 \%)$.

Keywords: steel, heat treatment, pit corrosion, $\mathrm{CCS}, \mathrm{CO}_{2}$-injection, $\mathrm{CO}_{2}$-storage.
\end{abstract}

\section{Introduction}

Engineering a geological on-shore aquifer CCS-site (CCS Carbon Capture and Storage [1-3]) corrosion of the casing and injection pipe steels may become an issue when emission gases, e.g. from the combustion processes of power plants, are compressed into deep geological layers [4-8]. From thermal energy 
production it is known that the $\mathrm{CO}_{2}$-corrosion is sensitively dependent on alloy composition, contamination of alloy and media, environmental conditions like temperature, $\mathrm{CO}_{2}$ partial pressure, flow conditions and protective corrosion scales [6-16]. Considering different environments, aquifer waters and pressures, the analyzed temperature regime between $40^{\circ} \mathrm{C}$ and $60^{\circ} \mathrm{C}$ is a critical temperature region well known for corrosion processes [17-20].

High chromium steels exposed to a $\mathrm{CO}_{2}$-environment generally precipitate slow growing pits mainly comprised of $\mathrm{FeCO}_{3}$ (siderite) $[4,8,17,19,21]$. After the $\mathrm{CO}_{2}$ is dissolved to build a corrosive environment, the solubility of $\mathrm{FeCO}_{3}$ in water is low $\left(\mathrm{p}_{\mathrm{Ksp}}=10.54\right.$ at $\left.25^{\circ} \mathrm{C}\right)$. As a result of the anodic iron dissolution, a siderite corrosion layer grows on the alloy surface. These reactions have been described in detail by various authors $[7,17]$ and a precipitation model has been introduced by Han et al. [21], which was modified by Pfennig and Kranzmann [19]. In the initial stage, the steel is exposed to the corrosive environment, the $\mathrm{CO}_{2}$-saturated brine, where the carbon dioxide forms carbonic acid in contact with the aquifer water. A ferrous hydroxide passivating film can form when its solubility limit is exceeded. A first reaction step may be attributed to the formation of $\mathrm{Fe}[\mathrm{II}]$ compounds $\mathrm{Fe}(\mathrm{OH})_{2}[7,25]$, which leads to an increase of the local $\mathrm{pH}$ near the hydroxide film. Consequently, a ferrous carbonate film may be formed. Then the growth of the corrosion layer will proceed internally and externally depending on the various carbon and oxygen partial pressures. Localized corrosion may then start when the ferrous hydroxide film is locally damaged due to mechanical or chemical effects. The highly porous nonprotective ferrous carbonate is then exposed to the brine environment where the $\mathrm{pH}$ is lower. As a result, the ferrous carbonate film dissolves and the steel is locally depassivated. This is accompanied by corrosion and passive film dissolution in a lateral direction followed by the detachment of the carbonate film. The removal of the detached film causes the pit to grow wider because the same steps will occur from the beginning on the newly exposed surface.

This work is a follow-up of our initial work on the local corrosion phenomena presented at "Air Pollution 2010". In this paper the varying microstructures and their related corrosion behaviour of differently heat treated steels used for $\mathrm{CO}_{2}$ injection into saline aquifer water reservoirs are of special interest.

\section{Materials and methods}

Laboratory experiments were carried out to determine the dependence of heat treatment on pit corrosion behaviour. Different steels used as an injection pipe with $13 \%$ chromium and $0.46 \% \mathrm{C}(\mathrm{X} 46 \mathrm{Cr} 13,1.4034)$ as well as $0.2 \%$ carbon (X20Cr13, 1.4021) were tested. In addition, X5CrNiCuNb16-4 (1.4542) was investigated as typical steel used for geothermal pumps. The steels were heat treated differently following protocols usual in the field of metallurgy (table 1).

Exposure tests in $\mathrm{CO}_{2}$-saturated aquifer brine were carried out using samples of the alloys above with $8 \mathrm{~mm}$ thickness and $20 \mathrm{~mm}$ width and $50 \mathrm{~mm}$ length. A hole of $3.9 \mathrm{~mm}$ diameter was used for sample positioning. The surfaces were activated by grinding with $\mathrm{SiC}-$ Paper down to $120 \mu \mathrm{m}$ under water and dipping 
Table 1: $\quad$ Heat treatment of samples used in exposure experiments.

\begin{tabular}{|c|c|c|c|c|}
\hline material & heat treatment & $\begin{array}{c}\text { temperature } \\
{\left[{ }^{\circ} \mathrm{C}\right]}\end{array}$ & $\begin{array}{l}\text { hold time } \\
\text { [min] }\end{array}$ & $\begin{array}{l}\text { cooling } \\
\text { medium }\end{array}$ \\
\hline \multirow{5}{*}{$\begin{array}{c}\mathrm{X} 20 \mathrm{Cr} 13 \\
1.4021\end{array}$} & normalizing & 785 & 30 & air \\
\hline & hardenitig & 1000 & 30 & oil \\
\hline & hardening + tempering 1 & $1000 / 600$ & 30 & oil \\
\hline & hardening + tempering 2 & $1000 / 670$ & 30 & oil \\
\hline & hardening + tempering 3 & $1000 / 755$ & 30 & oil \\
\hline \multirow{5}{*}{$\begin{array}{c}\mathrm{X} 46 \mathrm{Cr} 13 \\
1.4034\end{array}$} & normalizing & 785 & 30 & air \\
\hline & hardening & 1000 & 30 & oil \\
\hline & hardening + tempering 1 & $1000 / 650$ & 30 & oil \\
\hline & hardening + tempering 2 & $1000 / 670$ & 30 & oil \\
\hline & hardening + tempering 3 & $1000 / 700$ & 30 & oil \\
\hline \multirow{5}{*}{$\begin{array}{c}\mathrm{x} 5 \mathrm{CrNiCuNb} 16-4 \\
1.4542\end{array}$} & normalizing & 850 & 30 & air \\
\hline & hardening & 1040 & 30 & oil \\
\hline & hardening + tempering 1 & $1040 / 550$ & 30 & oil \\
\hline & hardening + tempering 2 & $1040 / 650$ & 30 & oil \\
\hline & hardening + tempering 3 & $1040 / 755$ & 30 & oil \\
\hline
\end{tabular}

into acetone for ca. 5 sec.. Samples of each base metal were positioned within the liquid phase [17-19]. The brine (known to be similar to the Stuttgart Aquifer [23]: $\mathrm{Ca}^{2+}: 1760 \mathrm{mg} / \mathrm{L}, \mathrm{K}^{2+}: 430 \mathrm{mg} / \mathrm{L}, \mathrm{Mg}^{2+}: 1270 \mathrm{mg} / \mathrm{L}, \mathrm{Na}^{2+}: 90.100 \mathrm{mg} / \mathrm{L}$, $\mathrm{Cl}^{\prime}: 143.300 \mathrm{mg} / \mathrm{L}, \mathrm{SO}_{4}{ }^{2-}: 3600 \mathrm{mg} / \mathrm{L}, \mathrm{HCO}^{3-}: 40 \mathrm{mg} / \mathrm{L}$ ) was synthesized in a strictly orderly way to avoid precipitation of salts and carbonates. Flow control ( $3 \mathrm{NL} / \mathrm{h}$ ) of the technical $\mathrm{CO}_{2}$ into the brine was done by a capillary meter GDX600_man by QCAL Messtechnik GmbH, Munich. The pH after the experiments was between 5.2 and 5.6. The exposure of the samples between $24 \mathrm{~h}$ and $1500 \mathrm{~h}$ into corrosive CCS environment was disposed in a climate chamber according to the conditions at the geological site at Ketzin/Germany at $60^{\circ} \mathrm{C}$ at ambient pressure - each material in a separated reaction vessel (figure 1). X-ray diffraction was carried out in a URD-6 (Seifert-FPM) with CoK $\alpha$-radiation with an automatic slit adjustment, step 0.03 and count $5 \mathrm{sec}$. Phase analysis was performed by matching peak positions automatically with PDF-2 (2005) powder patterns. Mainly structures that were likely to precipitate from the steels were chosen of the ICSD and refined to fit the raw-data-files using POWDERCELL $2.4[22]$ and AUTOQUAN ${ }^{\circledR}$ by Seifert FPM.

Sample surfaces were analyzed with a light optical microscope Axiophot 2 by Zeiss. Here the kinetics were obtained by counting the pits per frame (6 frames per sample, 2 samples per parameter) and giving the average pit number. Pit widths were measured light optically and pit depths were obtained from 3-D-images. These 3-D-images were realized by the double optical system Microprof TTV by FRT. Mass gain was analyzed according to DIN 50905 


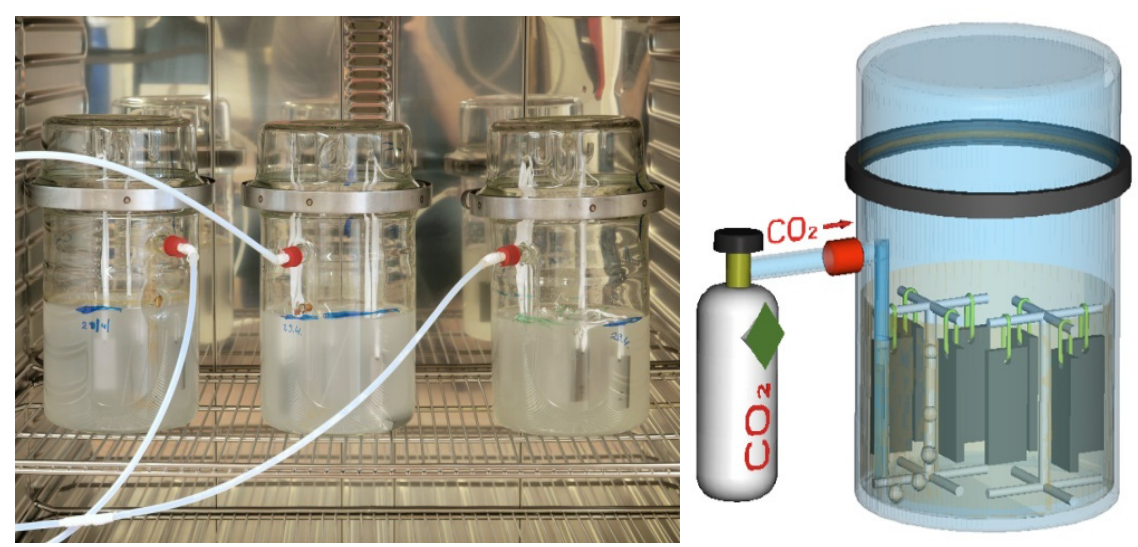

Figure 1: Experimental set up of laboratory corrosion experiment.

part 1-4. After surface analysis, the samples were embedded in a cold resin (Epoxicure, Buehler), cut and wet polished first with SiC-Paper from $180 \mu \mathrm{m}$ to $1200 \mu \mathrm{m}$. The finishing was done with diamond paste $6 \mu \mathrm{m}$ and $1 \mu \mathrm{m}$. Different light optical and electron microscopy techniques were used to investigate the layer structures and morphology of the samples.

\section{Results and discussion}

\subsection{Surface and morphology}

The complicated multi-layered carbonate/oxide structure is described in detail by Pfennig and Bäßler [17]. It reveals siderite $\mathrm{FeCO}_{3}$, goethite $\alpha-\mathrm{FeOOH}$, mackinawite FeS and akaganeite $\mathrm{Fe}_{8} \mathrm{O}_{8}(\mathrm{OH})_{8} \mathrm{Cl}_{1.34}$ as well as spinel-phases of various compositions. Carbides, such as $\mathrm{Fe}_{3} \mathrm{C}$, were identified within the corrosion layer, similar to the high-temperature corrosion phenomena [24]. The pits are covered with the same precipitates of the corrosion products formed on the surface elsewhere (figure 2).

\subsection{Kinetics: corrosion rate, amount of counted pits and maximum pit depth}

To evaluate the influence of the heat treatment the samples were examined via light optical methods to predict the amount of counted pits and the pit depths. Kinetics was obtained via weight loss according to DIN 50905 after exposure to the $\mathrm{CO}_{2}$-saturated aquifer water. The results are given in figures 3 to 5 with respect to corrosion rate, maximum penetration depth of pits and amount of counted pits. 


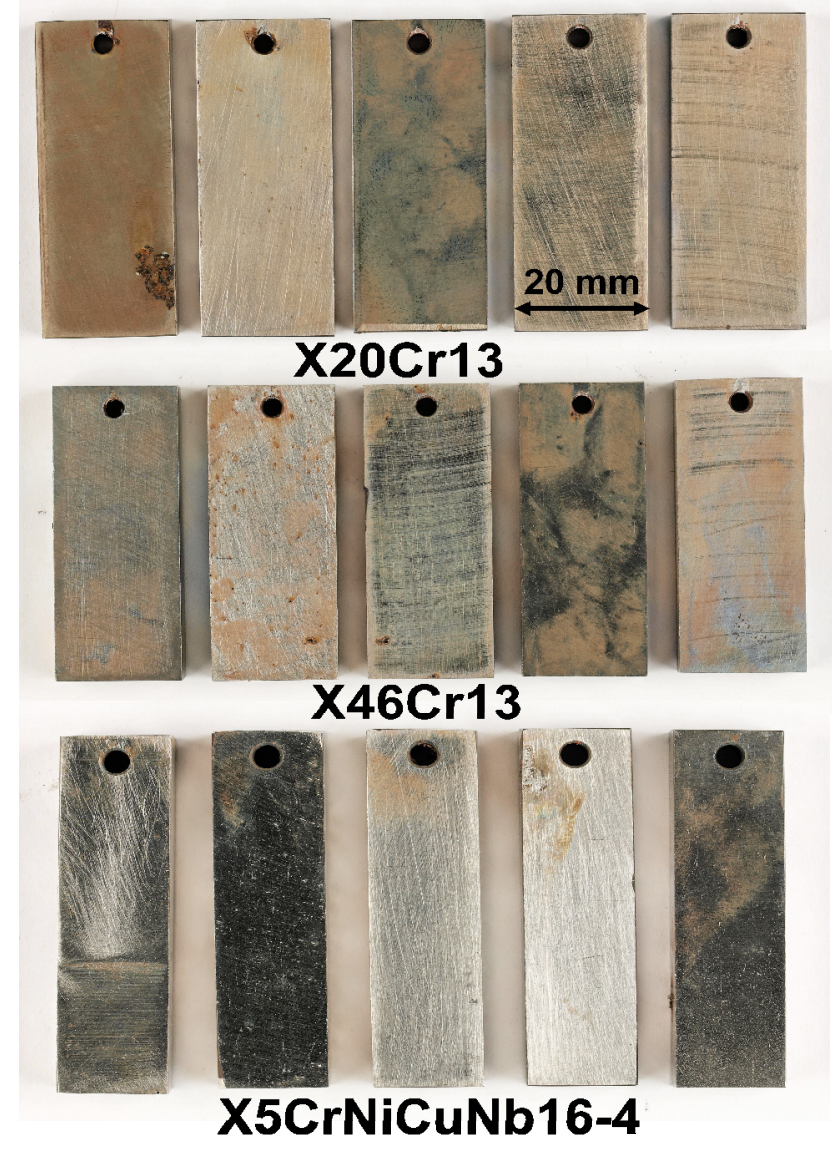

Figure 2: $\quad$ Surface images of precipitations and pits of differently heat treated samples of $13 \% \mathrm{Cr}$ steel $\mathrm{X} 46 \mathrm{Cr} 13$ after $6000 \mathrm{~h}$ exposure time.

\subsubsection{Corrosion rate}

The corrosion rate generally does not exceed $0.03 \mathrm{~mm} / \mathrm{year}$ and therefore is in good agreement with DIN 6601 allowing for $01 \mathrm{~mm} /$ year for pressure vessels. After $6000 \mathrm{~h}$ of exposure time all steels show an increase of corrosion rate. This may be due to the depassivation of the surface layers after long exposure to the $\mathrm{CO}_{2}$-saturated saline aquifer environment. Since the rate is very low, the increase may as well be related to the manual descaling procedure. For samples with more and deeper pits a longer etching time is required possibly resulting in partial dissolution of small layers of the base material. With corrosion rates obtained via mass gain method about $0.002 \mathrm{~mm} /$ year X5CrNiCuNb16-4 shows the lowest loss of base material for samples that were hardened or hardened and tempered. Normalized samples corrode around $0.01 \mathrm{~mm} /$ year determined after 6000 hours of exposure. The heat treatment does not influence the corrosion rate 


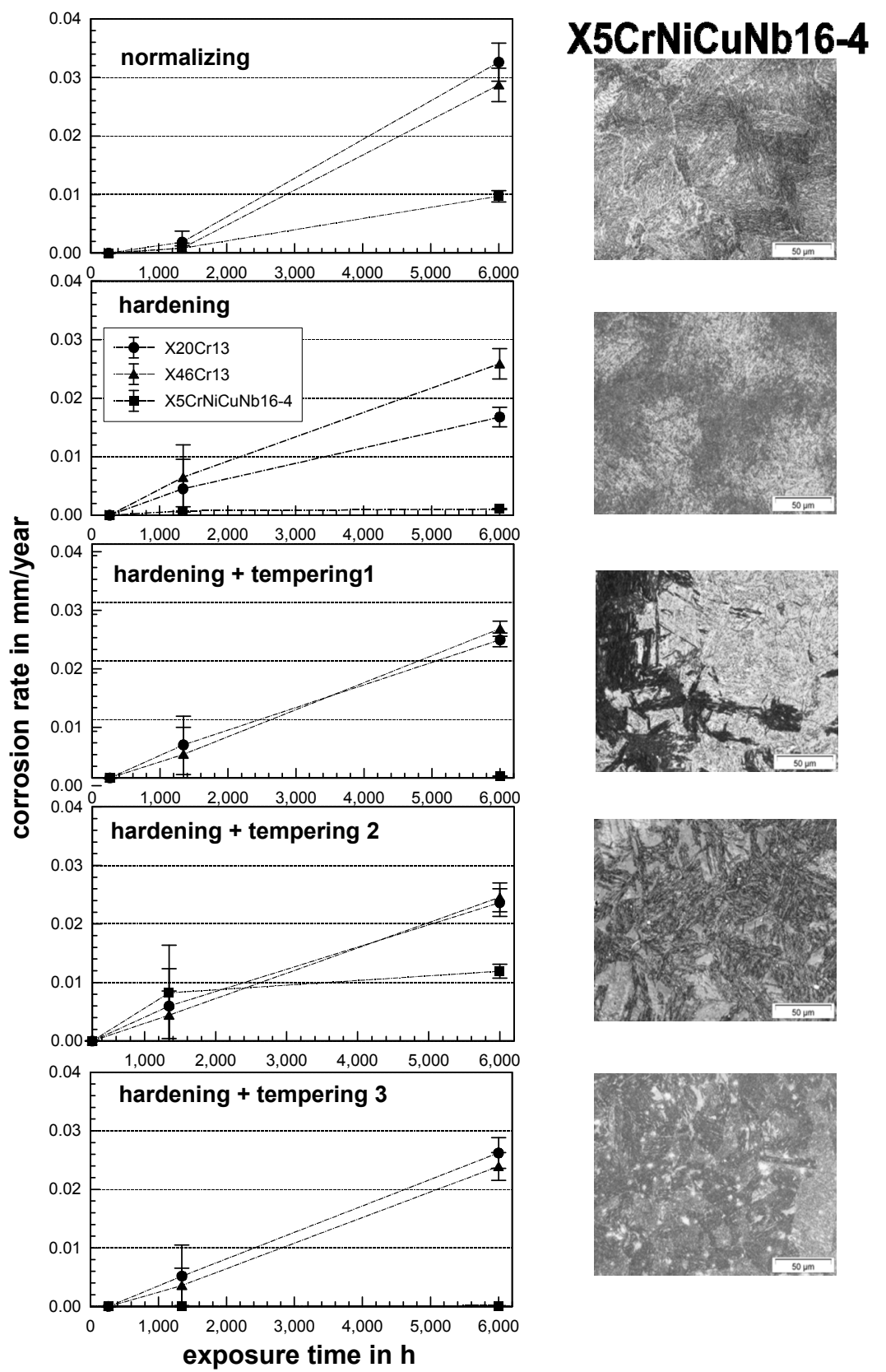

Figure 3: Corrosion rate after 6000 hours of exposure to aquifer brine water at $60{ }^{\circ} \mathrm{C}$ and ambient pressure (X20Cr13, X46Cr13 and $\mathrm{X} 5 \mathrm{CrNiCuNb16}-4$ (microstructure) heat treated prior to exposure. 


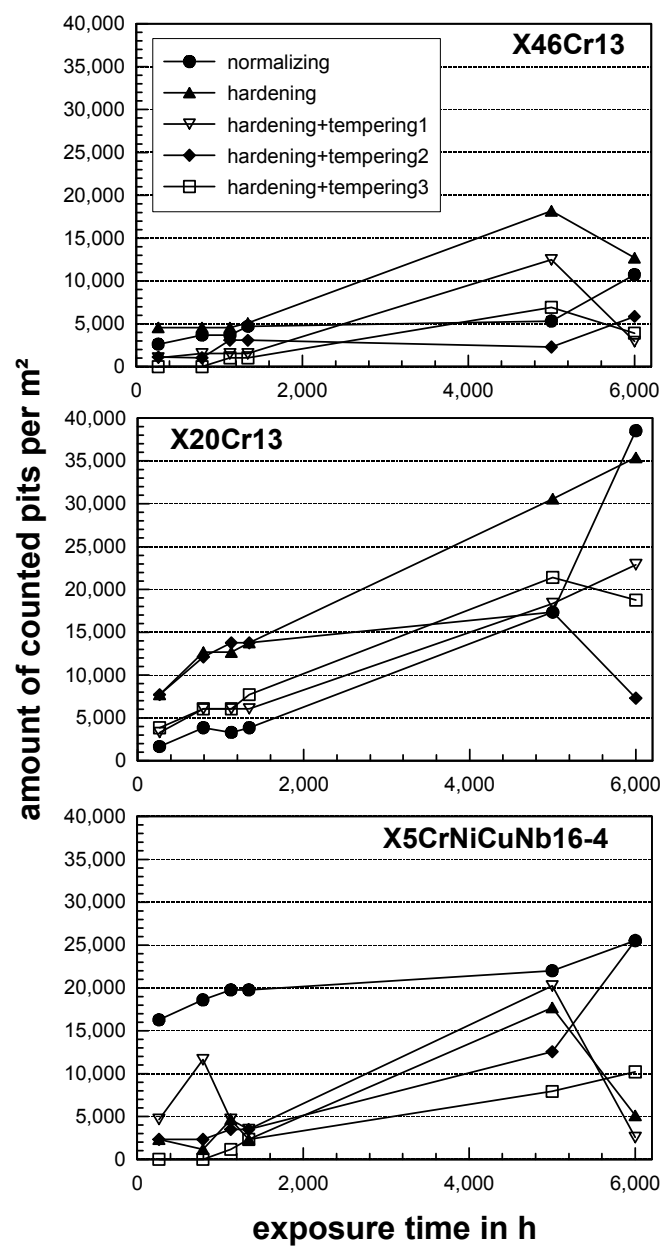

Figure 4: $\quad$ Amount of counted pits (6000 hours, $60{ }^{\circ} \mathrm{C}$ and ambient pressure).

of $\mathrm{X} 20 \mathrm{Cr} 13$ and $\mathrm{X} 46 \mathrm{Cr} 13$. These are comparable for both steels around $0.003 \mathrm{~mm} /$ year. Therefore hardening or hardening+tempering $\mathrm{X} 5 \mathrm{CrNiCuNb} 16-4$ would provide best corrosion resistance in a CCS-site borehole in a saline aquifer environment.

\subsubsection{Local corrosion (pit formation)}

Pits were obtained metallographically and via optical volume measurement and are found on all 3 steel qualities with maximum pit intrusion depths around $300 \mu \mathrm{m}$ for hardened X20Cr13 with martensitic microstructure after $6000 \mathrm{~h}$ of exposure. Overall figure 4-6 reveal that pit depths measured on $\mathrm{X} 46 \mathrm{Cr} 13$ do not penetrate as deep as pits measured on the other steel samples. Still, the heat treatment does not influence the maximum penetration depth significantly except 

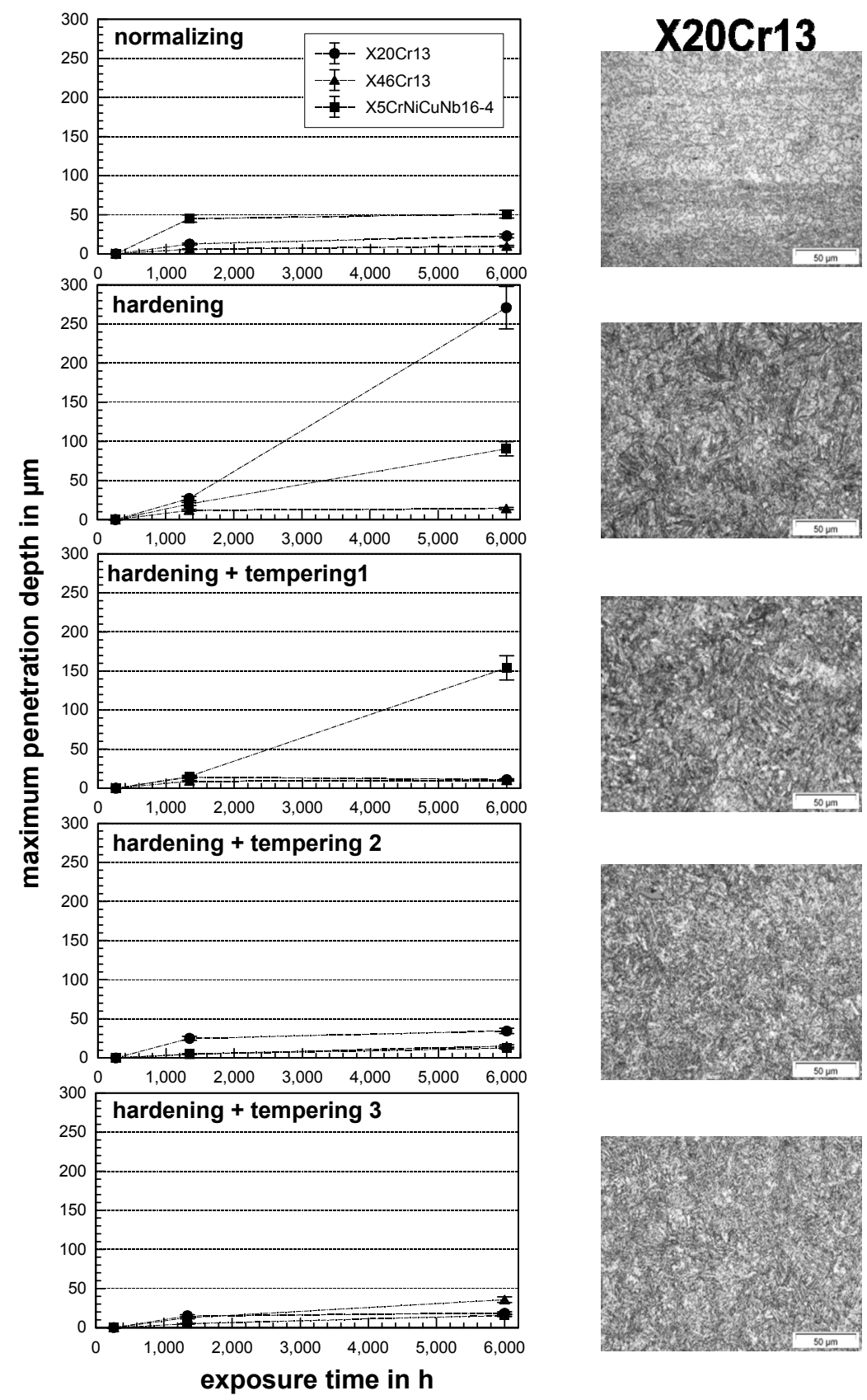

Figure 5: Maximum penetration depth after 6000 hours of exposure at $60^{\circ} \mathrm{C}$ and ambient pressure of X20Cr13 (microstructure), X46Cr13 and $\mathrm{X} 5 \mathrm{CrNiCuNb16-4}$ heat treated prior to exposure. 
for hardened samples and $\mathrm{X} 5 \mathrm{CrNiCuNb} 16-4$ hardened + tempering1. For the $13 \mathrm{Cr}$ steels $(\mathrm{X} 20 \mathrm{Cr} 13$ and $\mathrm{X} 46 \mathrm{Cr} 13)$ normalizing and hardening+tempering1 show less intrusion $(8-25 \mu \mathrm{m})$ than the other heat treatments, while hardening+tempering 2 and 3 seem to be best for X5CrNiCuNb16-4 (10 $\mu \mathrm{m})$.

\subsubsection{Amount of counted pits}

The heat treatment has little influence on the amount of counted pits per unit area, because there is little to no lowest amount of counted pits for one distinct heat treatment. The least amount of pits is found on $\mathrm{X} 46 \mathrm{Cr} 13$. Comparing steels with the same chromium content of $13 \%$ the higher carbon content in $\mathrm{X} 46 \mathrm{Cr} 13$ $(0.46 \% \mathrm{C})$, results in a lower amount of pits compared to X20Cr13 $(0.20 \%)$. For $\mathrm{X} 20 \mathrm{Cr} 13$ and $\mathrm{X} 46 \mathrm{Cr} 13$ hardening and tempering $2 / 3$ samples show the lowest amount of pits after $6000 \mathrm{~h}$ while $\mathrm{X} 5 \mathrm{CrNiCuNb} 16-4$ has a rather high number of pits per $\mathrm{m} 2$. The lower amount of pits on different samples after $6000 \mathrm{~h}$ of exposure is due to surface corrosion phenomena: that is that pits consolidate to shallow pit corrosion and are not longer counted as single pits. These surface corrosion products prevent the access of corrosive media to the bulk material.

Figure 6 reveals typical surfaces with localized corrosive attack measured via optical profilometer. Pit depth was demonstrated in figure 5. Pit depth is a statistical phenomenon and cannot be predicted easily. Penetration depth of ca. $600 \mu \mathrm{m}$ after 8 months of exposure will give pit growth rates over $0.1 \mathrm{~mm} /$ year and indicate that these steels have to be monitored carefully but may still be suitable for injection pipes in CCS environments.

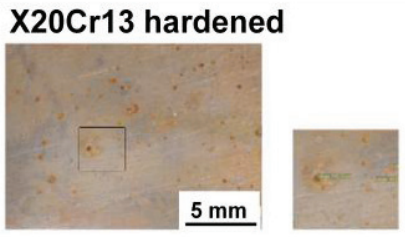

X5CrNiCuNb16-4 hardened
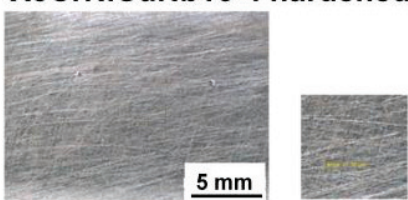
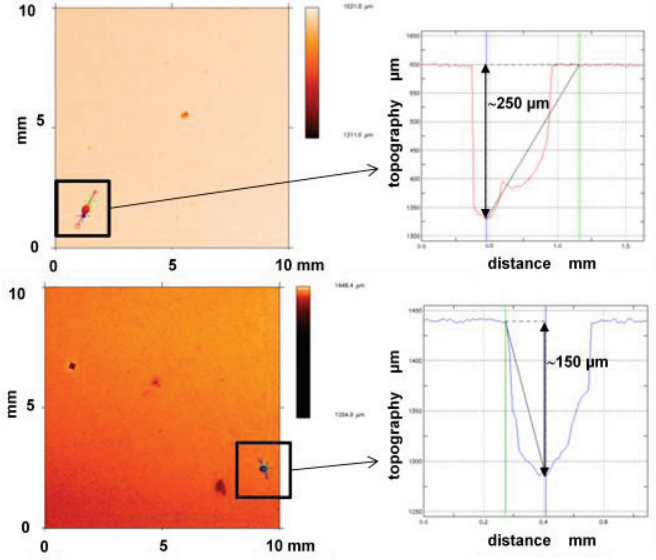

Figure 6: Typical surfaces and surface profiles with severe pit corrosion attack after 6000 hours of exposure at $60^{\circ} \mathrm{C}$ and ambient pressure of $\mathrm{X} 20 \mathrm{Cr} 13$ and $\mathrm{X} 5 \mathrm{CrNiCuNb} 16-4$ hardened prior to exposure.

\section{Conclusion}

Pit growth cannot be calculated as easily as surface corrosion rates because of its low predictability. Therefore, it is not possible to give corrosion rates and 
lifetime predictions regarding pit corrosion in CCS technology. Summarizing the kinetic results the heat treatment preferred to obtain the least corrosive attack is normalizing or hardening+tempering2 for $\mathrm{X} 20 \mathrm{Cr} 13$ and $\mathrm{X} 46 \mathrm{Cr} 13$. For $\mathrm{X} 5 \mathrm{CrNiCuNb} 16-4$ the combination hardening+tempering 3 should be preferred. For heat treatments regarding hardening and tempering a significant good corrosion resistance cannot be given. Although pit growth rates will be above $0.1 \mathrm{~mm} /$ year but below $1 \mathrm{~mm} /$ year it may still be possible that the analysed steel qualities are suitable for injection pipes in CCS environments if monitored closely. In future long term exposure experiments and detailed microstructure analysis will be necessary.

\section{Acknowledgements}

This work was supported by the FNK (Fachkonferenz für wissenschaftlichliche Nachwuchskräfte) of the Applied University of Berlin, HTW and by IMPACT (EU-Project EFRE 20072013 2/21). The authors would like to thank B. Linke of the HTW for the helpful contribution.

\section{References}

[1] D.C. Thomas, Carbon Dioxide Capture for Storage in Deep Geologic Formations, Volume 1, Elsevier Ltd UK 2005, ISBN 0080445748.

[2] M. van den Broek, R. Hoefnagels, E. Rubin, W. Turkenburg, A. Faaij, Effects of technological learning on future cost and performance of power plants with CO2 capture, Internal report: NWS-S-2008-10 (2009).

[3] GeoForschungszentrum Potsdam, CO2-SINK - drilling project, description of the project PART 1 (2006) 1-39.

[4] S. Nešić, "Key issues related to modelling of internal corrosion of oil and gas pipelines - A review", Corrosion Science 49 (2007) 4308-4338.

[5] S. Hurter, Impact of Mutual Solubility of $\mathrm{H} 2 \mathrm{O}$ and $\mathrm{CO} 2$ on Injection Operations for Geological Storage of CO2, International Conference of the Properties of Water and Steem ICPWS, Berlin, September 8-11.

[6] L. Zhang, J. Yang, J.S. Sun, M. Lu, Effect of pressure on wet H2S/CO2 corrosion of pipeline steel, No. 09565, NACE Corrosion 2008 Conference and Expo, New Orleans, Louisiana, USA, March 16th - 20th, 2008.

[7] L. J. Mu, W. Z. Zhao, Investigation on Carbon Dioxide Corrosion Behaviors of $13 \mathrm{Cr}$ Stainless Steel in Simulated Strum Water, Corrosion Science, Manuscript No. CORSCI-D-09-00353 (2009) 1-24.

[8] M. Bonis, Weight loss corrosion with H2S: From facts to leading parameters and mechanisms, Paper No. 09564, NACE Corrosion 2008 Conference and Expo, New Orleans, Louisiana, USA, March 16th - 20th, 2008.

[9] J. Enerhaug, A study of localized corrosion in super martensitic stainless steel weldments, a thesis submitted to the Norwegian University of Science and Technology (NTNU), Trondheim 2002. 
[10] V. Neubert, Beanspruchung der Förderrohrtour durch korrosive Gase, VDIBerichte Nr. 2026, 2008.

[11] R. Kirchheiner, P. Wölpert, Qualifizierung metallischer Hochleistungswerkstoffe für die Energieumwandlung in geothermischen Prozessen, VDIBerichte Nr. 2026, 2008.

[12] H. Zhang, Y. L Zhao, Z. D. Jiang, Effects of temperature on the corrosion behaviour of $13 \mathrm{Cr}$ martensitic stainless steel during exposure to $\mathrm{CO} 2$ and Cl- environment, Material Letters 59 (2005) 3370-3374.

[13] J. N. Alhajji and M. R. Reda, The effect of alloying elements on the electrochemical corrosion of low residual carbon steels in stagnant CO2saturated brine, Corrosion Science, Vol. 34, No. 11 (1993) 1899-1911.

[14] Y.-S. Choi and S. Nešić, Corrosion behaviour of carbon steel in supercritical CO2-water environments, No. 09256, NACE Corrosion 2008 Conference and Expo, New Orleans, Louisiana, USA, March 16th-20th, 2008.

[15] X. Jiang, S. Nešić, F. Huet, The Effect of Electrode Size on Electrochemical Noise Measurements of Mild Steel, 09575, NACE Corrosion 2008, New Orleans, Louisiana, USA, March 16th - 20th, 2008.

[16] Z. Ahmad, I.M. Allam, B.J. Abdul Aleem, Effect of environmental factors on the atmospheric corrosion of mild steel in aggressive sea coastal environment, Anti Corrosion Methods and Materials, 47 (2000) 215-225.

[17] A. Pfennig, R. Bäßler, "Effect of CO2 on the stability of steels with $1 \%$ and $13 \% \mathrm{Cr}$ in saline water" Corrosion Science, Vol. 51, Issue 4 (2009) 931940 ,

[18] A. Pfennig, A. Kranzmann, "Influence of $\mathrm{CO} 2$ on the corrosion behaviour of AISI 420 and AISI 4140...", Air Pollution XVII , Volume 123 (2009) 409-418, ISBN: 978-1-84564-195-5, ISSN: 1746-448X.

[19] A. Pfennig, A. Kranzmann, The role of pit corrosion in engineering the carbon storage site Ketzin, Germany, WIT Transactions on Ecology and the Environment, Volume 126, (2010) 109-118, ISBN: 978-1-84564-450-5.

[20] http://www.standard.no/pronorm-3/data/f/0/01/36/9_10704_0/M$506 \mathrm{~d} 1 \mathrm{r} 2 . \mathrm{pdf}$, " $\mathrm{CO} 2$ corrosion rate calculation model".

[21] J. Han, Y. Yang, S. Nešić, B. N. Brown, Roles of passivation and galvanic effects in localized CO2 corrosion of mild steel, Paper No. 08332, NACE Corrosion 2008, New Orleans, Louisiana, USA, March 16th -20th, 2008.

[22] S. W. Kraus, G. Nolze, POWDER CELL, J. Appl. Cryst. (1996), 29, 301303.

[23] A. Förster et al., Baseline characterization of the CO2SINK geological storage site at Ketzin, Germany: Environmental Geosciences, V. 13, No. 3 (2006), pp. 145-161.

[24] A. Kranzmann, D. Huenert, H. Rooch, I. Urban, W. Schulz, W. Österle, Reactions at the interface between steel and oxide scale in wet $\mathrm{CO} 2$ containing atmospheres, NACE Corrosion Conference \& Expo, Atlanta, 2009. 